\title{
Effect of dietary selenium and vitamin E supplementation on productive and reproductive performance in rams
}

\author{
A. A. Baiomy ${ }^{1}$, A. E. A.Mohamed ${ }^{2}$, A. A. Mottelib ${ }^{3}$

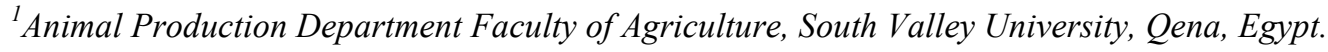 \\ ${ }^{2}$ Animal Medicine Department Faculty of Veterinary Medicine, South Valley University, Qena, Egypt. \\ ${ }^{3}$ Animal Medicine Department Faculty of Veterinary Medicine, Assiut University, Assiut, Egypt.
}

\begin{abstract}
The studies were carried out on 32 rams of the ossimi breed ( 270 days of age). Sixteen rams (group 1) received a ration containing $0.2 \mathrm{ppm}$. Se, and $30 \mathrm{mg}$ vit.E, the other $16 \mathrm{rams}$ (group 2) received $0.5 \mathrm{ppm}$. Se, and $50 \mathrm{mg}$ vit.E/ $/ \mathrm{kg}$ feed mixture .The feeding test was conducted from 270 days until 360 days of age. During the experiment the rams were subjected to live evaluations, i.e. testes circumference, libido level, semen characteristics, as well as selenium concentration and glutathione peroxidase (GSH-Px) activity in blood serum and seminal plasma. Routine macroscopic and microscopic analyses of semen quality were accompanied by measurement of Se content and GSH-Px activity in blood and semen. The Se concentration in blood plasma, seminal fluid and spermatozoa was measured by fluorometric method, while the GSH-Px activity by method based on NADPH - coupled reaction .Comparing the results in animals of both groups, it was clear that the all were in good health conditions as ascertained by clinical examination. No significant variation was detected in body weight of animals of both groups. Significant elevation $(p<0.05)$ in the values of semen conc., semen conc./ ejac, semen motion , sperm motility / ejac.as well as total sperms count were observed in animals of group 2 as compared to those of group 1 .
\end{abstract}

Great deal of information has recently become available for better nutrition strategies concerning feeding minerals and vitamins to livestock Selenium is an essential trace nutrient for humans and animals. It is an element fulfilling a significant function in reproduction processes, both in females and males of farm animals (Zachara et al .,1993a;1993b ; Wallace et al.,1983; Wu et al., 1979; Heimann et al.,1984; Kotowska and Kotowski,2001;MarinGuzman et al, 2000a).

It was suggested that vitamins play a key role in thermoregulation of rectal and scrotal skin temperature during heat stress and maintain libido, semen quality, and fertility (El-Darawany, 1999). Selenium acts to help and prevent oxidation of the sperm cell, thus aiding in maintaining sperm cell integrity (Cohen and Takasaki,1986; Zhang et al,1989; Chu et al.,1996), Selenium represents an integral component of glutathione peroxidase (GSH-Px), an enzyme which, along with vitamin $\mathrm{E}$, protects cell internal structures against free radicals and is an antioxidant for cellular membrane lipids [Ursini et al., 1999), Glutathione peroxidase activity has also been reported in human seminal plasma (Saaranen et al.,1989), and is present in the head and midpiece of sperm cells (Godeas et $a l, 1997)$.Serum selenium is reported to be low in men with oligospermia ,. Selenium deficiency has been linked to reproductive problems in sheep and cattle (Combs and Combs, 1986) and leads to largely immotile and a high incidence of sperm midpiece defects. In males bred on a low selenium diet, male hypogonadism was found as well as reduced production and deteriorated semen quality (Peretz et al., 1991;Kleene, 1993) and supplementation with selenium has been reported to improve reproductive performance in sheep. It was demonstrated that a diet supplemented with selenium and vitamin E improved sperm quality an effect possibly linked to the antioxidant properties of this vitamin. (Brzezinska-Slebodzinska et al., 1995; MarinGuzman et al., 1997). The aim of the present study is to evaluate the influence of increased addition of dietary selenium and vitamin $\mathrm{E}$ on reproductive performance of rams, body weight as well as the general health condition of animals. 
Table (1):Chemical composition and nutritive value of complete mixtures .

\begin{tabular}{lccc}
\hline \multirow{2}{*}{\multicolumn{1}{c}{ Item }} & \multicolumn{3}{c}{ Mixtures } \\
\cline { 2 - 4 } & & G1 & G2 \\
\hline Metabolizable energy & $(\mathrm{MJ})$ & 12.8 & 12.8 \\
Dry matter & $(\%)$ & 89.73 & 89.73 \\
Crude protein & $(\%)$ & 18.01 & 18.01 \\
Ether extract & $(\%)$ & 3.923 & 3.93 \\
Crude fibre & $(\%)$ & 9.83 & 9.83 \\
N-free extractives & $(\%)$ & 51.08 & 51.08 \\
Ash & $(\%)$ & 6.88 & 6.88 \\
Vitamin E & $(\mathrm{mg})$ & 30.0 & 60.0 \\
Selenium & $(\mathrm{ppm})$ & 0.20 & 0.50 \\
\hline
\end{tabular}

\section{Material and Methods}

This study was carried out in the Animal Production Experimental farm Faculty of Agriculture, South Valley University:, Egypt during the period from (August till ; December 2007 ). A number of the 32 rams of the Ossimi. Rams were chosen healthy and clinically free of external and internal parasites. Palpation of the external genitalia showed that they were typically normal. The rams were fed on the same diet from 230 to 270 days of age. In table (1). Chemical composition and nutritive value of complete mixtures At 270 days, Animals of the work were divided into two groups each of 16 rams. Each group of animals represents an experiment. The allocation to the groups was made with analogues method, i.e. from one litter one ram was assigned to a group. Foods were sampled weekly and dry matter intake (DM1, $\mathrm{kg} /$ day) was recorded daily till the termination of the experiment. Water was available all day and mineral were supplied in salt licking stones. Proximate analysis on dry matter basis (AOAC ,1990) of feed used is illustrated in Table (1).feeding test was carried out from 270 to 360 days of age. During the feeding test the rams of the group. 1 were fed on standard diet, which contained $0.2 \mathrm{ppm}$. Se and $30 \mathrm{mg}$ vitamin E per $1 \mathrm{~kg}$. While the group. 2 received $0.5 \mathrm{ppm}$. $\mathrm{Se}$ (Se yeast) and $60 \mathrm{mg}$ vitamin E per $1 \mathrm{~kg}$ of the ration. According to NRC (National Research Council, 1998 ),
The rams were housed in individual pens. The daily feed ration was gradually increased along with the increasing body weight. Chemical composition and nutritive value of the diets are given in table (1). The body weight of the rams, their daily gains, and feed conversion for the test period were determined at the age of 270 and 360 days. At age of 270 and 360 days the testes were measured. Upon completion of the test (from 360 days of age) on the rams were trained, and the collection of semen began, which was carried out with gloved hand technique.

Semen collection technique. The experimental rams were sexually stimulated by allowing two false mounts prior to first ejaculation. One false mount, followed by two minutes restraint, then a second false mount followed by two minutes restraint ended by the ejaculation (Almquist and Hale, 1973). When two ejaculates were collected, there was no false mount prior to second ejaculation. Semen was collected once weekly between 8.00 and 10.00 am using an artificial vagina

Semen physical characteristics. After collection, semen of each ejaculate was transferred immediately to the laboratory and was subjected to the following examinations: ejaculate volume $(\mathrm{ml})$, percentage of sperm motility and sperm concentration / $\mathrm{ml}\left(\mathrm{x}_{10}{ }^{9}\right)$. Ejaculate volume was measured directly in milliliters to the nearest $0.1 \mathrm{ml}$ using a transparent graduated glass tube. For evaluation of percentage of motility a drop of semen was examined under the low power of a microscope using a hot stage at $37^{\circ} \mathrm{c}$. Progressive motility was estimated on a percentage score .Number of spermatozoa / $\mathrm{ml}$ of semen was determined using a heamocytometer. Total and motile sperm out put / ejaculate were calculated. Routine macroscopic and microscopic analyses of semen.

Adopted methods. The seminal fluids as well as the blood plasma samples were separated and stored at $-20 \mathrm{C}$ till analysis. The activity of GSH - PX in both blood plasma and seminal fluids were determined according to Pagila and Valentine, (1967), while selenium concentrations were estimated with the fluorometric method of Watkinson, (1966). The basic nutrient concentrations in the feeds were determined with standard methods, and amino acids were measured using an automatic analyzer (Beckman Instruments Inc.). 
Tables (2): Body weight and testes circumference of control and treated rams.

\begin{tabular}{llc}
\hline \multicolumn{1}{c}{ Traits } & \multicolumn{2}{c}{ Groups } \\
\cline { 2 - 3 } & Group 1 & Group 2 \\
\hline Body weight (kg) : & $38.63 \pm 2.34^{\text {a }}$ & $38.41 \pm 2.12^{\text {a }}$ \\
Initial Body weight(kg) & $49.23 \pm 1.099^{\text {a }}$ & $49.53 \pm 1.03^{\text {a }}$ \\
Final Body weight(kg) & $106.0 \pm 33.97^{\mathrm{a}}$ & $111.2 \pm 36.0^{\text {a }}$ \\
Daily gain to 380 day of life (g) & & \\
Testes circumference (cm): & $23.29 \pm 0.22^{\text {a }}$ & $23.12 \pm 0.14^{\text {a }}$ \\
$\quad$ At 270days of age & $25.54 \pm 0.25{ }^{\text {a }}$ & $26.83 \pm 0.31^{\text {a }}$ \\
\hline
\end{tabular}

$\mathrm{A}, \mathrm{b}$ means in the same row followed by the same letter are not significantly different $(\mathrm{p}>0.05)$.

Table(3): Semen traits, selenium(Se)content and activity of glutathione peroxidase in the semen plasma and blood plasma of Rams as affected by Selenium and vitamin $E$ supplementation in the ration.

\section{Semen characteristics}

Selenium and vitamin $\mathbf{E}$ level

Group 1

0.2ppm Se+30mgE
Group 2

$0.5 \mathrm{ppmSe}+60 \mathrm{mgE}$

\begin{tabular}{|c|c|c|c|}
\hline Ejaculate volume $(\mathrm{ml})$ & $0.81 \pm 0.02$ & $0.89 \pm 0.04$ & Ns \\
\hline Concentration $/ \mathrm{ml}\left(\mathrm{x}^{10} 0^{9}\right)$ & $2.79 \pm 0.18$ & $3.02 \pm 0.53$ & $*$ \\
\hline Concentration /ejac (x109) & $2.26 \pm 0.39$ & $2.69 \pm 0.35$ & $*$ \\
\hline Semen motility & $82.50 \pm 0.01$ & $86.67 \pm 2.50$ & $*$ \\
\hline Motile sperm /ml $\quad\left(\mathbf{x 1 0}^{9}\right)$ & $2.30 . \pm 2.95$ & $2.61 . \pm 3.11$ & * \\
\hline Motile sperm /ejac $\left(\mathrm{x}^{0} 0^{9}\right)$ & $1.86 \pm 1.21$ & $2.33 \pm 1.63$ & * \\
\hline Total sperm count ( $\left.\mathrm{n} \times 10^{9}\right)$ & $20.2 \pm 8.0$ & $26.2 \pm 9.3$ & * \\
\hline Se in semen plasma $\left(\mu \mathrm{g} \cdot \mathrm{ml}^{-1}\right)$ & $0.042 \pm 0.017$ & $0.050 \pm 0.00$ & $*$ \\
\hline GSH-Px in semen plasma $\left(U \cdot \mathrm{ml}^{-1}\right)$ & $0.310 \pm 0.146$ & $0.233 \pm 0.085$ & $*$ \\
\hline Se in blood plasma $\left(\mu \mathrm{g} \cdot \mathrm{ml}^{-1}\right)$ & $0.267 \pm 0.049$ & $0.280 \pm 0.045$ & Ns \\
\hline GSH-Px in blood plasma $\left(U \cdot \mathrm{ml}^{-1}\right)$ & $4.00 \pm 0.014$ & $4.28 \pm 0.012$ & Ns \\
\hline
\end{tabular}

$*=$ Significantly different $(\mathrm{p}<0.05)$.

Statistical analysis. Data were statistically analyzed according to the General Linear Model (G L M) and the differences between means were detected by Duncan's Multiple Range Test (Duncan, 1995), S A S (1992).

\section{Results and Discussion}

Table 2, showed that Body weight gains and feed efficiency between animals of group 1 and 2 correspond to the results of Mahan and Parrett, 1996, who did not find any influence that adding Se to rations for rams but in contrast with the findings of Gabbedy 1971., Wilkins et al., 1982, who found an increase in body weight of rams supplemented with selenium

Rams of group 2 exhibited by $26.83 \pm 0.31$ $\mathrm{cm}$ larger testes circumference compared with those of the group 1, 25.54 $\pm 0.25 \mathrm{~cm}$. The differences found between the groups were, however, statistically non-significant that agrees with. Marin-Guzman et al., 2000a, but , Wallace et al., 1983, observed underdevelopment of testes and reduced production of spermatozoa in mice receiving selenium-deficient diets. On the other hand , Zachara et al.,1993a,1993b reported that selenium has a good effect on the sexual activity in rams .

As in table (3). The semen of rams in group 2 showed significantly higher $(\mathrm{p} \leq 0.05)$ sperm concentration and total sperm count compared to animals of group 1 ,Morphological evaluation of spermatozoa in the ejaculates of the rams demonstrated that an addition of $0.5 \mathrm{ppm} \mathrm{Se}+$ $60 \mathrm{mg}$ vitamin $\mathrm{E}$ to $1 \mathrm{~kg}$ of feed reduced considerably the percentage of morphologically changed spermatozoa.

A positive effect of selenium on sperm concentration and morphology has been previously confirmed by Heimann et al., 1984; Behne, 1996; Marin-Guzman et al., 2000b, Buchanan-Smith et al.(1969) mentioned the lack of univocal dependencies between the concentration of the studied microelements on 
the reproductive organs, blood, semen and morphological changes in bull sperms .

It was demonstrated in studies on rams Marin-Guzman et al 1997, that adding vitamin E alone in an amount of $220 \mathrm{IU} / \mathrm{kg}$ of ration was of little effect in relation to morphological changes in spermatozoa or other traits. This implies that antioxidants, $\mathrm{Se}+$ vitamin $\mathrm{E}$, which act synergistically, should be administered jointly (Buchanan-Smith et al., 1969; and Mahan and Parrett., 1996). The elevation in the values of blood plasma selenium and GSH-PX in rams of group 1 , table 3 agree with the previous reported findings of Marin-Guzman et al, (1997), in boars, and Aberden, et al., (1980) in bulls .

On the other hand, GSH-Px activity was by $20 \%$ lower $(p \leq 0.05)$ in seminal plasma of group 2 rams, despite the fact that the latter exhibited much better semen quality than the rams of the group 1. The obtained results confirm the suggestion that most selenium in an organism occurs in proteins other than, as it was once assumed, in GSH-Px (Norton and McCarthy., 1986). Higher selenium concentration in seminal plasma of the animal of group 2 enables a conclusion that the element is a component of other selenoproteins that positively influence the rams' reproductive performance. New selenoproteins have been identified over the recent years, e.g. selenoprotein-P, which is beneficial to animal reproduction (Arthur , 1994). Vitamin E is a potent antioxidant that works primarily to stabilize dangerous free radicals that are formed in fatty tissues and membranes. However, Se is a component of the enzyme GSH-PX that protects cellular membranes and lipid containing organelles from peroxidative damage. Thus the synergistic action of these two elements seems to be very essential and important for the well production and reproduction efficiencies in rams. Increased addition of selenium and vitamin $\mathrm{E}$ to balanced feed mixtures fed to rams, from the currently recommended standard amounts $0.2 \mathrm{ppm} \mathrm{Se}+$ $30 \mathrm{mg}$ vitamin E per $1 \mathrm{~kg}$ to $0.5 \mathrm{ppm} \mathrm{Se}+60 \mathrm{mg}$ vitamin $\mathrm{E}$ per $1 \mathrm{~kg}$ has a minor effect on testes size and libido traits of the ram, positively influences both quantitative and qualitative semen traits, and increase body weight.

\section{References}

Almquist, I.O. and Hale, E. B. (1973): An approach to the measurement of sexual behavior and semen production of dairy bulls. $3^{\text {rd }}$ Inter. Conger. Animal Report. Plenary Cambridge.
AOAC. (Association of Official Analytical Chemists) (1990): Official Methods of Analysis. $15^{\text {th }}$ ed. Arlington, VA: AOAC.

Arthur, J.R. (1994): The biochemical functions of selenium: relationships to thyroid metabolism and antioxidant systems. The Rowett Research Institute Annual report 1993. The Rowett Research Institute.

Behne, D.; Weiler, H. and Kyriakopoulos, A. (1996): Effects of selenium deficiency on testicular morphology and function in rats. J. Rep. Fert., 106: 291-297.

Brzezinska-Slebodzinska, E.A.B.; Slebodzinski, B.; Pietras and Wieczorek, G. (1995): Antioxidant effect of vitamin $\mathrm{E}$ and glutathione on lipid peroxidation in boar semen plasma. Biol. Trace Elem. Res., 47:69-74.

Buchanan-Smith, J.G.; Nelson, E.C.; Osburn, B.I.; Wells, M.E. and Tillman, A.D. (1969): Effects of vitamin $\mathrm{E}$ and selenium deficiencies in sheep fed a purified diet during growth and reproduction. J. Anim Sci., 29, 808.

Chu, F.F.; DeSilva, H.A.R.; Esworthy, R.S.; Boteva, K.K.; Walters, C.E.; Roses, A.; Rao, P.N. and Pettenati, M.J., (1996): Polymorphism and chromosomal localization of the GI-form of human glutathione peroxidase (GPX2) on 14 q24.1 by in situ hybridization. Genomics, 32: 272-276.

Cohen, H.J. and Takahashi, K. (1986): Human plasma glutathione peroxidase isolation and characterization of a unique selenium enzyme. In: Proceedings of the $78^{\text {th }}$ Annual National Meeting of the American Society for Clinical Investigation. Washington, DC: ASCI; May: 34.

Combs, G.F. and Combs, S.B.; (1986): The Role of Selenium in Nutrition. San Diego: Academic Press.

Duncan, D.B. (1955): Multiple ranges and multiple F-test Biometrics, 11:1-42.

El-Darawany, A.A. (1999): Improving semen quality of heat stressed rams in Egypt. Indian J. of Anim. Sci., 69:1020-1023.

Gabbedy, B.G., (1971): Effect of selenium on wool production body weight and mortality of young sheep in Western Australia . Aust. Vet. J., 47:(7) 318- 322

Heimann, E. D.; Smith, M. F.; Morris, J.S.; Gall, T.J.; Elmore, R.G. and Morrow, R.E. (1984): Relationships among spermatozoal abnormalities and the selenium concentration of blood plasma, semen, and reproductive tissues in young bulls. Anim. Report. Sci., 7: 315-321.

Kleene, K.C. (1993): The Mitochondrial Capsule Selenoprotein - A Structural Protein in the Mitochondrial Capsule of Mammalian Sperm, in: Selenium in Biology and Human Health, ed. R.F. Burk, Springer-Verlag, New York 7:135-149.

Kotowska, E. and Kotowski, B. (2001): Znaczenie selenu $\mathrm{i}$ witaminy $\mathrm{E} w$ reprodukcji świń [Significance of selenium and $E$ vitamin in pig reproduction]. Prz. Hod. 7:9-11 [in Polish].

Mahan, D.C., and Parrett, N.A. (1996): Evaluating the efficacy of Se-enriched yeast and sodium selenite on tissue Se retention and serum glutathione peroxidase activity in sheep. J. Anim. Sci., 75: 2994-3003.

Marin-Guzman, J.; Mahan, D.C.; Chung, Y.K.; Pate, J.L. and Pope, W.F. (1997): Effects of dietary selenium and vitamin $\mathrm{E}$ on boar performance and tissue responses, semen quality, and subsequent fertilization rates in mature gilts. J. Anim. Sci., 75:2994-3003.

Marin-Guzman, J.; Mahan, D.C. and Pate, J.L. (2000a): Effect of dietary selenium and vitamin $\mathrm{E}$ on spermatogenesis development in boars. J. Anim. Sci., 78: 1537-1543. 
Marin-Guzman, J.; Mahan, D.C. and Whit Moyer, R. (2000b): Effect of dietary selenium and vitamin E on the ultra structure and ATP concentration of boar spermatozoa, and the efficacy of added sodium selenite in extended semen on sperm motility. J. Anim. Sci., 78:1544-1550.

Norton, S.A. and McCarthy, F.D. (1986): Use of injectable vitamin $\mathrm{E}$ and selenium-vitamin $\mathrm{E}$ emulsion in ewes and suckling lambs to prevent nutritional muscular dystrophy. J. Anim. Sci,. 62:496-508.

NRC . (National Research Council) (1998): Nutrient Requirements of Sheep, $10^{\text {th }}$ ed., National Academy Press, and Washington, D.C.

Paglia D.E. and Valentine W.N. (1967): Studies on quantitative characterization of erythrocyte glutathione peroxidase. J. Lab. Clin. Med., 70:158-169.

Peretz, A.; Neve, J.; Duchateau, J.; Siderova, V.; Huygen, K.; Famaey, J. P. and Carpentier, Y. A. (1991): Effects of selenium supplementation on immune parameters in gut failure patients on home parenteral nutrition. Nutrition, 7:215-221.

Saaranen, M.; Suistomaa, U. and Vanha, P.T. (1989): Semen selenium content and sperm mitochondrial volume in human and some animal species. Hum Reprod., 4:304308.

S .A .S. (1992): statistical Analysis System User, Quide :Basis. SAS Inst .Inc Cary.NC.

Takasaki, N.; Tonami, H. and Simizu, A. (1987): Semen selenium in male infertility. Bull Osaka Med. Sch., 33:8796.

Ursini, F.; Heim, S.; Kiess, M.; Maiorino, M.; Roveri, A.; Wissing, J. and Flohe, L. (1999): Dual function of the selenoprotein PHGPx during sperm maturation. Sci., 285:1393-1396.

Wallace, E.; Calvin, H.I. and Cooper G.W. (1983): Progressive effects observed in mouse sperm during course of three generations of selenium deficiency. Gamete Res., 4: 377-387.

Watkinson, J.H. (1966): Fluorometric determinations of selenium in biological material with 2,3, diaminonaphtalene. Anal. Chem., 38: 92-103.

Wilkins, J. V.; Kilgour, R.J.; Gleeson, A.C.; Cox, R.J.; Geddes, S.J. and Simpson, I.H. (1982): Production responses in selenium supplemented sheep in northern New South Wales. 2. Live weight gain, wool production and reproductive performance in young merino ewes given selenium and copper supplements. Aus. J. Exp. Agricult. Animal husb.

Wu, S.H.; Oldfield, J.E.; Shull, L.R.; Cheeke, P. R. (1979): Specific effect of selenium deficiency on rat sperm. Biol. Report., 20:793-798.

Zhang, L.; Maiorino, M.; Roveri, A. and Ursini, F. (1989): Phospholipids hydro peroxide glutathione peroxidase specific activity in tissues of rats of different age and comparison with other glutathione peroxidase. Biochim Biophys Acta, 1006:140-143.

Zachara, B. A.; Mikolajczak, J. and Trafikowska, U. (1993a): Effect of Various Dietary Selenium (Se) Intakes on Tissue Se Levels and Glutathione Peroxidase Activities in Lambs. J. Vet. Med. A, 40:310-318.

Zachara, B.A.; Trafikowska, U.; Labedzka, H. and Mikolajczak, J. (1993b): Effect of dietary Se intake on blood Se levels and glutathione peroxidase activities in lambs. Small Rum. Res., 9:331-340.

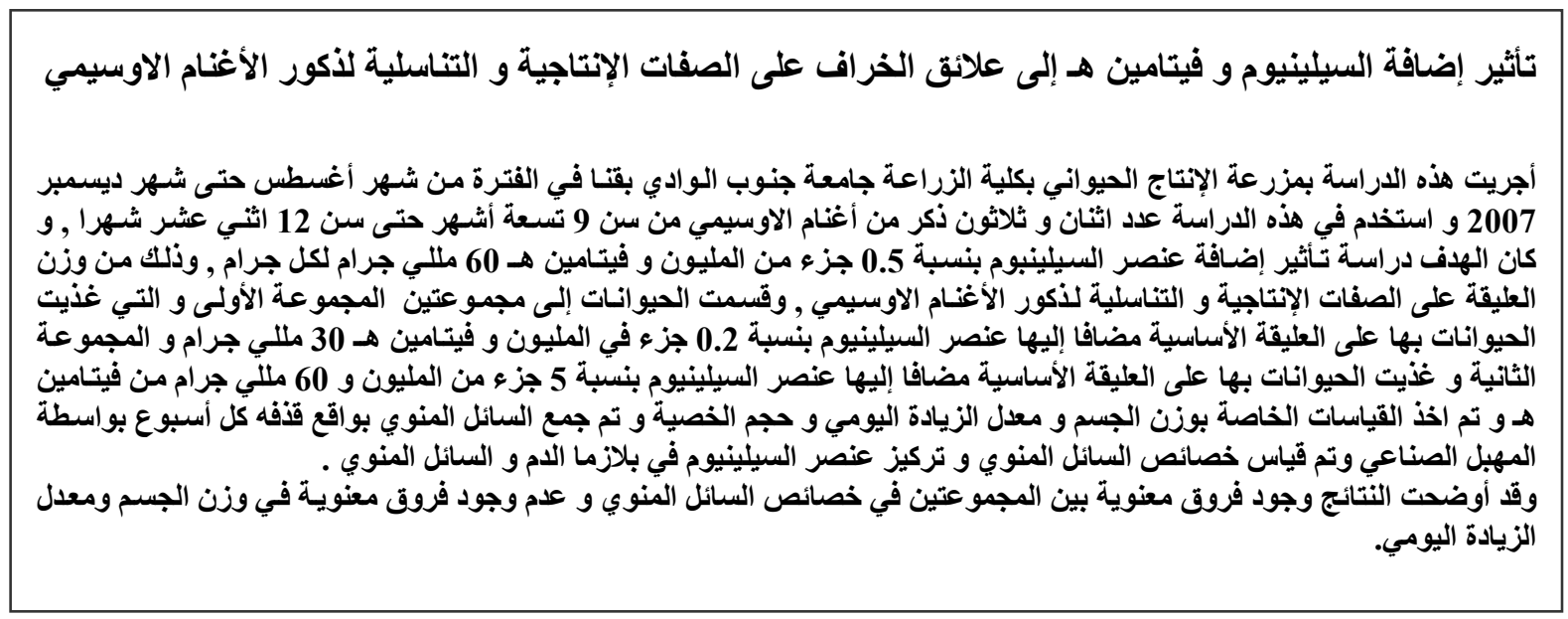

